\title{
THE ANALYSIS OF $\alpha$-CRYSTALLINE PROTEIN IN WHITE AND BRUNESCENT CATARACT
}

\author{
MUHAMMAD HIDAYAT ${ }^{*}$, ELLYZA NASRUL ${ }^{2}$, TJAHJONO GONDHOWIHARJO ${ }^{3}$, ANDANI EKA PUTRA ${ }^{4}$
}

${ }^{1}$ Department of Ophthalmology, Medical Faculty, Andalas University, Padang, West Sumatra, Indonesia. ${ }^{2}$ Department of Clinical Pathology, Medical Faculty, Andalas University, Padang, West Sumatra, Indonesia. ${ }^{3}$ Department Ophthalmology, Medical Faculty, Indonesia University, Jakarta, Indonesia. ${ }^{4}$ Department of Microbiology, Medical Faculty, Andalas University, Padang, West Sumatra, Indonesia

Email: mhidayatspmk@gmail.com

Received: 10 May 2021, Revised and Accepted: 05 July 2021

\section{ABSTRACT}

Objectives: The objectives of the study were to determine the difference of concentration and expression of $\alpha$-crystalline protein in white and brunescent cataract lenses.

Methods: The design of this study is cross-sectional comparative. The subject was cataract patients who underwent cataract surgery in Puskesmas Pariaman, West Sumatra, Indonesia. Lens examination was carried out at the Microbiology Laboratory of FK Unand from July 2019 to February 2020. The samples consisted of 36 subjects who met the inclusion criteria. ELISA examination was used to determine the concentration of $\alpha$-crystalline protein and Western Blot examination was performed to see the expression of the $\alpha$-crystalline protein in all subjects.

Results: The difference in the concentration of $\alpha$-crystalline protein in white cataract and brunescent cataract was not statistically significant, with $p=0.129(p>0.05)$. The result of Western blot examination was normal expression of $\alpha$-crystalline protein in white cataract and under expression of $\alpha$-crystalline protein in brunescent cataracts.

Conclusion: The expression of $\alpha$-crystalline protein appeared to be different between white and brunescent cataract lenses. In brunescent cataract, under expression of $\alpha$-crystalline proteins was related to the decrease of chaperone activity. This change occurred allegedly because of photochemical reaction that happened inside the lens.

Keywords: $\alpha$-Crystalline protein, White cataract, Brunescent cataract.

(C) 2021 The Authors. Published by Innovare Academic Sciences Pvt Ltd. This is an open access article under the CC BY license (http://creativecommons.org/ licenses/by/4.0/) DOI: http://dx.doi.org/10.22159/ajpcr.2021v14i9.42012. Journal homepage: https://innovareacademics.in/journals/index.php/ajpcr

\section{INTRODUCTION}

Cataract is a condition of lens transparency loss caused by biomolecular and chemical processes of the crystalline protein of the lens, which results in opacification of the lens that will cause visual disturbances. Cataract is one of the causes of blindness in the eye [1]. The nucleus of the cataract lens undergoes physical and chemical changes, such as changes in the crystalline protein of the lens, increased pigmentation, and rigidity [2].

The lens nucleus gradually solidifies and hardens progressively, changes color from transparent to yellowish gray to brown and even black. The color change corresponds to an increase in the hardness of the lens nucleus. The hardness of the lens nucleus is ranked based on the consistency and color of the nucleus, observed by slit lamp biomicroscopy. The color of the cataract lens nucleus can determine the degree of cataract hardness, classified into: Grade 1, soft nucleus (transparent); Grade 2, slightly hard nucleus, semi-soft (white, yellowish white); Grade 3, moderately hard nucleus, medium (yellow); Grade 4, hard nucleus (brownish yellow, brown); and Grade 5, very hard nucleus (brown to blackish) are also called "brunescent" cataract and "black" [3]

In brunescent cataract, the difficulty level of cataract surgery is much more difficult due to the very hard lens nucleus, compared to non-cataracts brunescent (Kim WS and Kim KH, 2016). This condition makes it difficult to perform cataract surgery with phacoemulsification techniques, because the ultrasonic energy used during cataract surgery is bigger and longer, thus increasing the risk of intra and post-operative complications [4].

Lens proteins are divided into two groups based on their solubility level, namely, water soluble protein fraction and water insoluble protein fraction.
The water-soluble protein fraction is about $90 \%$ of the total lens protein and consists mainly of a group of protein known as crystallines. Crystalline proteins consist of $\alpha-, \beta$-, and $\gamma$-, which are the main proteins in the human lens. Alpha crystals which are classified into small heat shock proteins act as chaperones that bind to denatured proteins by forming high molecular weight aggregates to maintain their solubility, while beta and gamma crystals act as structural support for the lens [5]. This study assessed differences in alpha protein levels in white and brunescent cataracts.

\section{METHODS}

This study was an observational study with a cross-sectional comparative study design that took place in Puskesmas Pariaman, West Sumatra-Indonesia from October to December 2018, approved by the ethics committee with registered number 152/UN.16.2/KEP-FK/2020. The subjects of this study were senile cataract patients who underwent cataract surgeries using extracapsular cataract extraction technique and met the inclusion criteria. Congenital, traumatic, and complicated cataract were excluded from this study.

We included 36 cataract patient based on clinical and ophthalmogical examination by the ophthalmologist. After the patient was diagnosed with cataracts, the pupil was dilated with mydriacyl followed by a slit lamp examination to determine the degree of the lens nucleus hardness. The image of the lens was documented in a file format (.jpg). Based on this data, cataracts were divided into two groups, namely, white and brunescent cataract. Baseline characteristics were recorded on a separate sheet, which included age, sex, history of diabetes, use of steroid drugs, and history of smoking.

The lens tissue was retrieved using ECCE procedure. The lens tissue was obtained in a dissolved form and has been mixed with $5 \mathrm{ml}$ of 
the solvent. The hard lens tissue was destroyed using a homogenizer. This sample was put into a $15 \mathrm{ml}$ tube to be stored at $-20^{\circ} \mathrm{C}$ until it was used for examination. The same condition applies to the lens capsule.

ELISA examination is intended to measure the concentration of alpha crystalline protein chains. $100 \mathrm{ul}$ of the lens and capsule homogenate sample were inserted into the well which had contained specific antibodies to the target protein. After several washing steps, secondary antibodies were added with peroxidase enzymes (Horseradish Peroxidase, HRP). Furthermore, Tetramethylbenzidine substrate was added. The color formed was read using a wavelength of $450 \mathrm{~nm}$. The level of $\alpha$-crystalline proteins obtained from this examination was then analyzed statistically using SPSS program.

Western Blot examination is intended to assess the expression of alpha crystalline protein chains that present in the lens tissue and lens capsule. Ten ul of lens tissue suspension and capsules were inserted into SDS-PAGE gel and run at 60 volts for $30 \mathrm{~min}$, after that, it was transferred to the blotter. Protein identification uses alpha crystalline antibodies. Expression was determined by comparing band thickness with housekeeping proteins such as beta actin.

\section{RESULTS}

The subjects in this study consisted of 18 patients with white cataract and 18 patients with brunescent cataracts. The data obtained were grouped and tabulated according to their respective characteristics as shown in Table 1.

In Table 1, it can be seen that there were more female than male cataract patients. Surgery was performed in the age range of 60-69 years, about $50 \%$ for white cataract and age $70-79$ years, about $38.9 \%$ for brunescent cataract. Subject's occupations described in Table 2 shows that, generally most of the patients had more outdoor activities than indoor activities in both white and brunescent cataracts group.

The crystalline protein $\alpha$-concentration obtained in ELISA examination on white and brunescent cataracts is shown in Table 3 .

\begin{tabular}{llllll}
\hline \multirow{2}{*}{ Table 1: Gender of patients with white and brunescent cataract } \\
\hline \multirow{2}{*}{ Gender } & \multicolumn{2}{l}{ White cataract } & & \multicolumn{2}{l}{ Brunescent cataract } \\
\cline { 2 - 3 } \cline { 5 - 6 } & $\mathbf{n}$ & $\mathbf{\%}$ & & $\mathbf{n}$ & $\mathbf{9}$ \\
\hline Man & 7 & 38.9 & & 9 & 50 \\
Woman & 11 & 61.1 & & 9 & 50 \\
Total & 18 & 100 & & 18 & 100 \\
\hline
\end{tabular}

Table 2: Occupation of patients with white and brunescent cataracts

\begin{tabular}{llllll}
\hline \multirow{2}{*}{ Occupation } & \multicolumn{2}{l}{ White cataract } & & \multicolumn{2}{l}{ Brunescent cataract } \\
\cline { 2 - 3 } & $\mathbf{n}$ & $\mathbf{\%}$ & & $\mathbf{n}$ & $\mathbf{\%}$ \\
\hline Indoor & 6 & 33.3 & & 5 & 27.8 \\
Outdoor & 12 & 66.7 & & 13 & 72.2 \\
Total & 18 & 100 & & 18 & 100 \\
\hline
\end{tabular}

Table 3: Concentration of $\alpha$-crystalline protein in white and brunescent cataracts using the ELISA method

\begin{tabular}{lll}
\hline & White & Brunescent \\
\hline Mean & 0.253 & 0.213 \\
Median & 0.265 & 0.181 \\
Minimum & 0.097 & 0.107 \\
Maximum & 0.358 & 0.435 \\
\hline
\end{tabular}

Based on Table 3, it can be seen that the average concentration of $\alpha$-crystalline protein in white cataracts is higher than the $\alpha$-crystalline protein concentration in brunescent cataract. However, the minimum and maximum values of $\alpha$-crystalline protein in brunescent cataracts were higher than the minimum and maximum values of $\alpha$-crystalline protein in white cataracts. Table 4 shows the results of the bivariate analysis of a-crystalline protein in white and brunescent cataracts. We use Mann-Whitney statistical test to define the difference of concentration of $\alpha$-crystalline protein in white and brunescent cataracts because the data are not normally distributed.

The results of western blotting shows normal expression of $\alpha$-crystalline protein in white cataract (Sample 1-18) are shown in Fig. 1.

The results of western blotting showed under expression of $\alpha$-crystalline protein in brunescent cataract (Sample 19-36) are shown in Fig. 2.

\section{DISCUSSION}

In this study, of the 36 samples studied, more cataracts were found in women than men. In terms of age, it can be seen that most of them are in the age range of 60-69 years (50\%), and 70-79 years (38.9\%). In this study, the cataracts we studied were cataracts that occurred due to age factors or senile cataracts.

In this study, we found that more patients work outdoors, which is one of the risk factor for cataracts. Outdoor workers received more UV exposure than indoor workers. UV rays triggers oxidative stress, and cause a change of the crystalline protein from being water soluble to water insoluble. With aging and chronic oxidative stress, crystalline proteins undergo covalent chemical modification leading to the formation of high molecular weight aggregates, insoluble protein particles as well as increased pigmentation and cataracts. Individuals whose jobs are frequently exposed to UV rays (outdoor workers) have the highest risk of developing cataracts. Cataracts are one of the effects of damage caused by chronic exposure to UV rays. UV radiation is also frequently proposed as a major causative factor for brunescent cataract. Individuals with jobs frequently exposed to UV rays (outdoor workers) have the highest risk. The main factor affecting lens change is the wavelength of light absorbed by the lens. Research on normal human lenses in vitro shows that chronic exposure to UV rays causes the lens to turn brunescent $[4,6]$.

The oxidative stress that occurs due to exposure to UV rays is called oxidative photostress. Oxidative photostress comes primarily from the absorption of light by lens constituents such as proteins, enzymes, and DNA, and manifests as changes in lens function and causes cataract formation [7-9].

The processes of thiolation, deamination, glycation, carbamylation, phosphorylation, and acetylation as well as proteolysis can cause cutting and release of crystalline protein fragments, manifesting as changes in lens function and causing cataract formation. One form of cataract that is particularly common in tropical regions of the world is brunescent cataract or brown cataract. Epidemiological studies have found that the incidence of brunescent cataracts is higher in the tropical country. Brunescent cataract is characterized by a high amount ( $70 \%$ of total protein) waterinsoluble protein in the lens, high absorption, and UV radiation in areas included in the UV light spectrum, namely, the tropics [5,6].

Table 4: Analysis results (Mann-Whitney) of $\alpha$-crystalline protein concentration in white and $\alpha$-brunescent cataracts

\begin{tabular}{lcll}
\hline & $\mathbf{n}$ & $\begin{array}{l}\text { Median } \\
\text { (Minimum-Maksimum) }\end{array}$ & $\mathbf{p}$ \\
\hline $\begin{array}{l}\text { Concentration of protein } \\
\alpha \text {-in white cataract }\end{array}$ & 18 & $0.265(0.097-0.358)$ & 0.129 \\
$\begin{array}{l}\text { Concentration of protein } \\
\alpha \text {-in brunescent cataract }\end{array}$ & 18 & $0.181(0.107-0.435)$ & \\
\hline
\end{tabular}


Based on the results of statistical test analysis using Mann-Whitney test with $p$ value 0.129 , there was no significant difference between the mean of $\alpha$-crystalline protein concentration in white and brunescent cataracts. The results of western blotting showed a normal expression of $\alpha$-crystalline protein in white cataract and under expression of $\alpha$-crystalline protein in brunescent cataract.

Protein crystalline $\alpha$ - is the most dominant type, consisting one-third of the total crystalline lens. As known in cataracts, the crystalline lens protein change from being dissolved (water soluble) to be insoluble, which results in lens cloudiness. In the process of cataract formation, there is a change in the composition ratio of lens crystalline protein content, which is $90 \%$ of the total lens protein. In the white and brunescent cataract group, the function of $\alpha$-crystalline protein as a chaperone who keep the lens transparency begins to decrease, the lens begins to become cloudy and is dominated by crystalline protein $\gamma$-, which functioned as a buffer protein [10].

Yang et al. in their study found a decrease in mRNA and $\alpha$-crystalline protein expression in patients with congenital cataracts and senile cataracts. He explained that the degree of decrease in mRNA and protein expression really depends on the type of cataract. In his study, Yang et al. compared the concentration of $\alpha$-crystalline protein in congenital cataracts and senile cataracts through real time PCR examination, and found a reduction of expression. This reduction is thought to be closely related to differences in the cataractogenesis process in each type of cataract. Even with the different research methods, the decrease of protein value was found proportionate with decrease of its function as chaperons or small heat shock proteins that keep the lens transparency, that starts to decrease according to its concentration [10].

The modification of the crystalline extension of the lens by the processes of thiolation, deamination, glycation, carbamylation, phosphorylation and acetylation and proteolysis, causes aggregation and deterioration of chaperone function, which can change the dynamic state of the protein [5].

Of the three types of crystalline, alpha crystalline is the most dominant type, consisting one-third of the lens protein. Alpha crystalline consists of two subunits, named $A$ and $B$, which are covalently unrelated to form aggregates with an average molecular weight of $20 \mathrm{kDa}$ difference on the lens (Fig. 3).
The primary structures of the A and B subunits show a high level of homologation between them and small heat shock proteins, as they indicate the origin of the crystalline domains preserved in these proteins [11-13].

The second structure of the alpha crystalline subunit is mainly in the form of a b-sheet. The tertiary and quaternary structures of alpha crystals are still unknown. The crystalline domain A is thought to have folding structure, such as immunoglobulin. Alpha crystalline molecules are dynamic oligomeric molecules, with subunits that separate and constantly reassociate. This subunit exchange property is also involved in its activity as a chaperone, keeping the lens transparency from changing. Several studies have shown that subunit exchange is influenced by certain mutations in the $\alpha$-crystalline subunit or changes and undergoes age-related modifications. Both in vivo and in vitro studies, to understand the molecular basis of cataracts caused by crystalline mutations and age-related cataracts (senile), have shown a loss of chaperone activity and increased protein aggregation that plays a role in lens pathology. The three-dimensional structural delineation of the main constituent lens protein, $\alpha$-crystalline, has high sequential homology to the structural sequences of the $A$ and $B$ subunits. The use of mutagenesis directed to structure combination to construct structures for the $\alpha \mathrm{A}$ - and $\alpha \mathrm{B}$ crystalline oligomers [11-13].

In general, cataracts are characterized by opacification or decreased lens clarity and accumulation of pigments due to the Maillard reaction between glucose, lysine, and arginine, which are residues of lenticular proteins. The chromophore substance in the lens is also modified, such as a pale yellow discoloration of the lens to a more brownish color. Chromophore that undergoes this modification will display different fluorescence when exposed to UVA [2].

Kynurenine (kynurenine, N-for-mylkynurenine, 3-hydroxykynurenine [3HK], OBD-Glucoside, and 4-(2-amino-3-hydroxyphenyl)-4oxobutanoic acid OBD-Glucoside, quinoline group (quinaldic acid, kynurenic acid, xanthurenic acid, oxoxanthurenic acid and 4-(hydroxy 3-glycine)-quinoline), Group B-carbolines (2, 4, 7-11), and the argpyrimidine group are components of organic molecules found in all crystalline lens proteins $[14,15]$.

Fluorescent chromophores are formed from tryptophan compounds ("UV filter" compounds) such as GSH-3-OHKG, and 3HK, which form

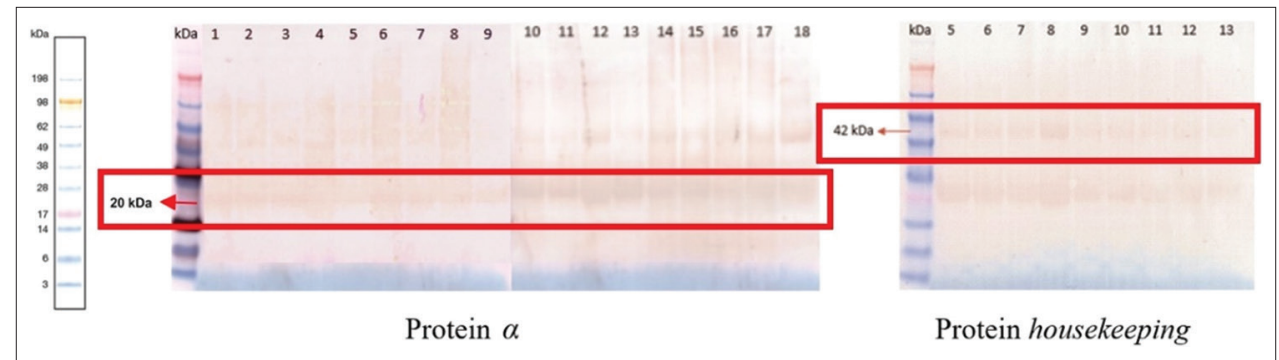

Fig. 1: Western blot comparison of $\alpha$-crystalline protein expression (left) compared with $\beta$ actin (right) as housekeeping protein from the lens of patients with white cataracts

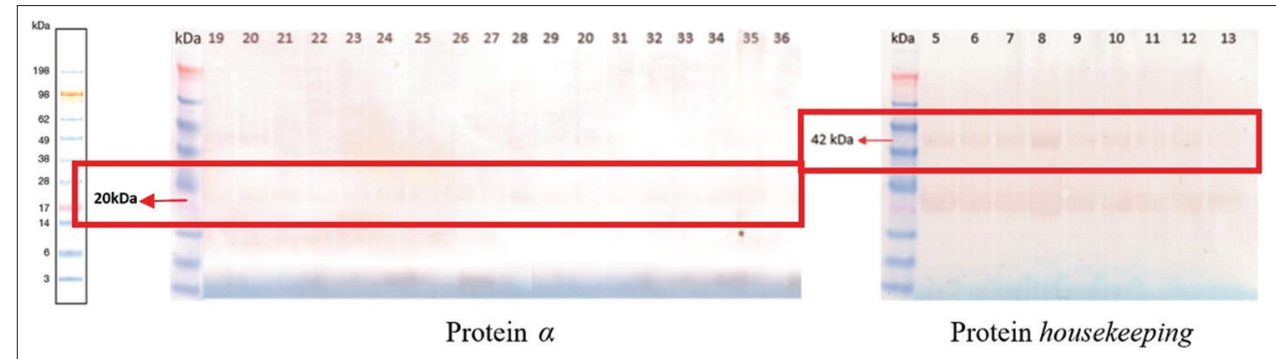

Fig. 2: Western blot comparison of $\alpha$-crystalline protein expression (left) compared with $\beta$ actin (right) as housekeeping protein from the lens of patients with brunescent cataracts 


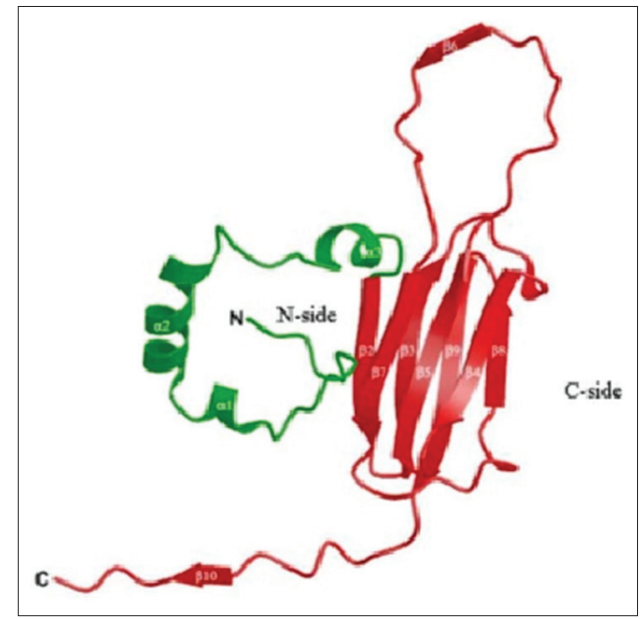

Fig. 3: Structure of $\alpha$-crystalline protein [5]

cross-linked derivatives with crystalline proteins. The main contributor to chromophore accumulation is the formation of Maillard products and AGEs as a result of glycation or ascorbylation. When there is accumulation of fluorescent chromophore, the lens opacity can turn yellow, brown, or black [16].

Brunescent cataract, a form of cataract that is particularly common in tropical regions of the world. Brunescent cataract is characterized by a high amount of water insoluble protein in the lens. This changes caused by photochemical reaction through high absorption and ultraviolet radiation in areas included in the UV light spectrum. Besides that, other chemical reaction also has a significant contribution [17].

When there is accumulation of fluorescent chromophores, as well as aggregation of lens proteins, the lens can turn into a yellow, brown, or black opacity. The Maillard reaction causes the structure of the lens to turn brown and causes a decarboxylation reaction. Thus, it is proved that the color change is associated with complex reaction pathways such as oxidative $\alpha$-dicarbonyl cleavage or the formation of dehydroascorbic acid and requires oxygen and a reaction called the Maillard reaction. The Maillard reaction starts with the reaction of a carbohydrate (reactive carbonyl group) with an amino group on the protein. Major chromophore comes from glucose degradation in the form of glucose auto oxidation process [5].

Chromophore accumulation is a major contributor to the formation of Maillard products and Advanced glycation endproducts (AGEs) as a result of glycation or ascorbylation which becomes reactive intermediate products and stable end products. When there is accumulation of fluorescent chromophore, the opacity of the lens can change to yellow, brown, or black and the modification of the protein as a result of this Maillard reaction causes the characteristics of the proteins to become brownish in color which cannot be changed with age. Hence, Maillard reactions have been considered a major contributor to age-related eye diseases such as cataracts $[5,18]$.

Long-term reduction of AGEs formation by dietary manipulation or lifestyle changes, reduced oxidative stress from UV exposure, and antioxidants, can reduce AGEs levels and help reduce the incidence of cataracts brunescent [19].

\section{CONCLUSION}

The expression of $\alpha$-crystalline protein appeared to be different between white and brunescent cataract lenses. In brunescent cataract, under expression of $\alpha$-crystalline proteins was related to the decrease of chaperone activity. This is a major cause of crystalline lens instability that leads to protein aggregation and an increase of insoluble protein fraction along with increased light scattering and loss of lens transparency which cause cataract.

\section{ACKNOWLEDGMENT}

This paper was supported by the Biomedical Laboratory of Medical Faculty of Andalas University, West Sumatra - Indonesia.

\section{AUTHOR CONSTRIBUTION}

The concept and method of this study were initiated by Muhammad Hidayat, as well as collecting the data and writing this manuscript. Ellyza Nasrul and Tjahjono Gondhowiharjo interpreted the data, analyzed the result, and built discussion. Andani Eka Putra analyzed the source literature and applied the statistics.

\section{CONFLICT OF INTEREST}

All the authors declared that they have no conflicts of interest to disclose in publishing this article.

\section{AUTHORS FUNDING}

All of the works and funds needed in this study were supported by the authors themselves.

\section{REFERENCES}

1. Liu YC, Wilkins M, Kim T, Malyugin B, Mehta JS. Cataracts. Lancet 2017;390:600-12.

2. Thiagarajan G, Shirao E, Ando K, Inoue A, Balasubramanian D. Role of xanthurenic acid 8-O- $\beta$-D-glucoside, a novel fluorophore that accumulates in the brunescent human eye lens. Photochem Photobiol 2002;76:368.

3. Praveen MR, Vasavada AR, Jani UD, Trivedi RH, Choudhary PK. Prevalence of cataract type in relation to axial length in subjects with high myopia and emmetropia in an Indian population. Am J Ophthalmol 2008;145:176-82.

4. Crispim J, Jung LS, Paz L, Allemann N, Schor P. The surgical challenges dense brunescent cataracts present. Expert Rev Ophthalmol 2015;10:13-22.

5. Michael R, Bron AJ. The ageing lens and cataract: A model of normal and pathological ageing. Philos Trans R Soc B Biol Sci 2011;366:1278-92.

6. Roberts JE. Ultraviolet radiation as a risk factor for cataract and macular degeneration. Eye Contact Lens 2011;37:246-9.

7. Alamri M, Alsammahi A, Alharbi M, Alshammari H, Alshehri M, Saeedi I, et al. Pathophysiology of cataracts. Int J Community Med Public Health 2018;5:3668.

8. Sreelakshmi V, Abraham A. Age related or senile cataract: Pathology, mechanism and management. Austin J Clin Ophthalmol 2016;3:1067.

9. Wang K, Spector A. $\alpha$-crystallin can act as a chaperone under conditions of oxidative stress. Investig Ophthalmol Vis Sci 1995;36:311-21.

10. Yang J, Zhou S, Guo M, Li Y, Gu J. Different alpha crystallin expression in human age-related and congenital cataract lens epithelium. BMC Ophthalmol 2016;16:1-6

11. Horwitz J. Alpha-crystallin. Exp Eye Res 2003;76:145-53.

12. Augusteyn RC. $\alpha$-crystallin: A review of its structure and function. Clin Exp Optom 2004;87:356-66.

13. Sharma KK, Santhoshkumar P. Lens aging: Effects of crystallins. Biochim Biophys Acta Gen Subj 2009;1790:1095-108.

14. Roberts JE, Finley EL, Patat SA, Schey KL. Photooxidation of lens proteins with xanthurenic acid: A putative chromophore for cataractogenesis. Photochem Photobiol 2001;74:740.

15. Padayatti PS, Ng AS, Ucbida K, Glomb MA, Nagaraj RH. Argpyrimidine, A blue fluorophore in human lens proteins: High levels in brunescent cataractous lenses. Investig Ophthalmol Vis Sci 2001;42:1299-304

16. Cheng R, Lin B, Ortwerth BJ. Separation of the yellow chromophores in individual brunescent cataracts. Exp Eye Res 2003;77:313-25.

17. Hiller R, Sperduto RD, Ederer F. Epidemiologic associations with nuclear, cortical, and posterior subcapsular cataracts. Am J Epidemiol 1986;124:916-25.

18. Linetsky M, Shipova E, Cheng R, Ortwerth BJ. Glycation by ascorbic acid oxidation products leads to the aggregation of lens proteins. Biochim Biophys Acta Mol Basis Dis 2008;1782:22-34

19. Li L, Chang B, Cheng C, Chang D, Hawes NL, Xia CH, et al. Dense nuclear cataract caused by the $\gamma \mathrm{B}$-crystallin $\mathrm{s} 11 \mathrm{r}$ point mutation. Investig Ophthalmol Vis Sci 2008;49:304-9. 